\title{
Antimicrobial activity of Ficus exasperata (Vahl) leaf extract in clinical isolates and its development into herbal tablet dosage form
}

\begin{tabular}{|c|c|}
\hline \multicolumn{2}{|c|}{$\begin{array}{l}\text { Authors: } \\
\text { Tolulope O. Ajala }{ }^{1} \\
\text { Ayobami J. Olusola }^{2} \\
\text { Oluwatoyin A. Odeku }\end{array}$} \\
\hline \multicolumn{2}{|c|}{$\begin{array}{l}\text { Affiliations: } \\
{ }^{1} \text { Department of } \\
\text { Pharmaceutics and Industrial } \\
\text { Pharmacy, University of } \\
\text { Ibadan, Ibadan, Nigeria }\end{array}$} \\
\hline \multicolumn{2}{|c|}{$\begin{array}{l}{ }^{2} \text { Department of } \\
\text { Pharmaceutics and } \\
\text { Pharmaceutical Technology, } \\
\text { Faculty of Pharmacy, Olabisi } \\
\text { Onabanjo University, } \\
\text { Ago-Iwoye, Nigeria }\end{array}$} \\
\hline \multicolumn{2}{|c|}{$\begin{array}{l}\text { Corresponding author: } \\
\text { Tolulope Ajala, } \\
\text { tolulola1721@gmail.com }\end{array}$} \\
\hline \multicolumn{2}{|c|}{$\begin{array}{l}\text { Dates: } \\
\text { Received: } 22 \text { May } 2020 \\
\text { Accepted: } 01 \text { Aug. } 2020 \\
\text { Published: } 19 \text { Oct. } 2020\end{array}$} \\
\hline \multicolumn{2}{|c|}{$\begin{array}{l}\text { How to cite this article: } \\
\text { Ajala, T.O., Olusola, A.J. \& } \\
\text { Odeku, O.A., 2020, } \\
\text { 'Antimicrobial activity of Ficus } \\
\text { exasperata (Vahl) leaf extract } \\
\text { in clinical isolates and its } \\
\text { development into herbal } \\
\text { tablet dosage form', Journal } \\
\text { of Medicinal Plants for } \\
\text { Economic Development 4(1), } \\
\text { a95. https://doi.org/10.4102/ } \\
\text { jomped.v4i1.95 }\end{array}$} \\
\hline \multicolumn{2}{|c|}{$\begin{array}{l}\text { Copyright: } \\
\text { (c) 2020. The Authors } \\
\text { Licensee: AOSIS. This } \\
\text { is licensed under the } \\
\text { Creative Commons } \\
\text { Attribution License. }\end{array}$} \\
\hline \multicolumn{2}{|l|}{ Read online: } \\
\hline 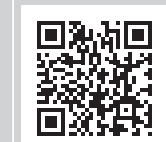 & $\begin{array}{l}\text { Scan this QR } \\
\text { code with your } \\
\text { smart phone or } \\
\text { mobile device } \\
\text { to read online. }\end{array}$ \\
\hline
\end{tabular}

Background: Ficus exasperata (Vahl) from the family Moraceae is a herb of ethnobotanical importance with antimicrobial properties. The past studies have been on the phytochemistry and pharmacological activities of the plant, but there is a need to formulate this valuable herb into tablet dosage form to offer standardisation.

Aim: The aim of this study was to assess the antimicrobial activity of $F$. exasperata leaf extract (extract) and formulate it into herbal tablet dosage form.

Setting: The experiments were performed at the laboratories of the Faculty of Pharmacy, University of Ibadan, Ibadan, Nigeria.

Methods: The extract was obtained by maceration and assessed for antimicrobial activity using agar cup diffusion method. Tablets were prepared by direct compression using Avicel ${ }^{\circledR}$, Lactose and Emcompress ${ }^{\circledR}$ at a drug-diluent ratio of 1:4 and 1:9. The flow properties of the powder mixtures were determined using compressibility index, Hausner's ratio, angle of repose and density measurements. The mechanical properties of the tablets were assessed using crushing strength (CS), friability (FR) and the crushing strength-friability ratio (CSFR) and release properties with disintegration times (DT), disintegration efficiency ratio and dissolution times. Analyses were carried out using two-way analysis of variance on Prism 5.0.

Results: The results showed that the extract had concentration-dependent antimicrobial activity. The flow properties of the powder mixtures were in the rank order of Avicel ${ }^{\circledR}>$ Lactose $>$ Emcompress $^{\circledR}$. Tablet CS and CSFR increased, whilst FR decreased with increase in compression force and diluent concentration. All tablets passed the DT test. The ranking of dissolution times was Avice ${ }^{\circledR}<$ Lactose $<$ Emcompress $^{\circledR}<$ no diluent.

Conclusion: Ficus exasperata extract demonstrated antimicrobial properties dependent on type of organism and extract concentration. The herbal tablets have acceptable mechanical and release parameters, which varied with diluent type, drug-diluent ratio and compression pressure.

Keywords: Ficus exasperata leaf extract; antimicrobial properties; diluents; direct compression; herbal tablets; mechanical and release properties.

\section{Introduction}

Traditional medicine has become the mainstay of about $80 \%$ of the people in developing countries for primary healthcare, and the use of herbal medicines in the treatment and management of diseases has increased in Africa (Ekor 2014). Thirty-nine per cent of the 520 new drugs approved during the period of 1983 through 1994 were either natural products or derivatives of natural products (Dias, Urban \& Roessner 2012).

A number of plants, including Ficus exasperata (Vahl), have been used in traditional medicine for many years because of their antimicrobial properties (Sofowora 1993). Ficus exasperata belongs to the family Moraceae, with 800 species occurring in the tropical part of the world, chiefly in Indomalaya and Polynesia (Odunbaku, Ilusanya \& Akasoro 2008). Ficus species are plants well known all over the world as 'fig plant'. Ficus exasperata, 'Eepin' in Yoruba language, western Nigeria, is a medicinal plant locally known as 'sand paper plant' and used for treating eyesores, stomach pains, ring worm infection (Abbiw 1990), leprosy, controlling bleeding and easing childbirth (Burkill 1997). In Nigeria, the young leaves of F. exasperata are prescribed as a common antiulcer remedy in addition to various pharmacological actions, such as antidiabetic, antihypertensive, lipid-lowering and antimicrobial activities, which have been reported for the extract (Buniyamin, Eric \& Fabian 2007; Sonibare, Isiaka \& Taruka 2006). 
In conventional medicine, most formulations contain synthetic active ingredients (Joy et al. 2001), whilst herbal remedies consist of natural plant material and hence are considered to cause low levels of side effects (Blumenthal et al. 1998). The increased use of herbs has led to the proliferation of herbal preparations in the market and most of them are presented as either decoctions or dry powdered plant parts for infusion in various liquids for different uses (Meyer, Afolayan \& Taylor 1996). However, the liquid dosage forms prepared as infusions, decoctions and concoctions present numerous challenges with regard to methods of preparation, analytical control procedures, stability of the products, appropriateness of dosage forms and dosage regimen (Agyemang \& Togbega 2005). In addition, past research revealed that the bulk of herbal medicinal products on sale in the south western part of Nigeria were of low pharmaceutical quality as they do not comply with pharmacopoeal limits (Okunlola, Adewoyin \& Odeku 2007). Therefore, the formulation of active herbal extracts into standardardised solid oral dosage forms such as tablets is highly desirable. Tablets are widely used solid dosage forms because they are convenient, presentable, compact, stable and cheaper to manufacture on a large scale; offer precise dosing and improve patient compliance.

In this study, the ethanol extract of F. exasperata leaf was evaluated for its antimicrobial effect and then formulated into herbal tablet dosage form by direct compression using different diluents; the mechanical and release properties were also assessed. The successful outcome of this study is expected to offer a herbal tablet dosage form with prospect for commercialisation in the treatment of infections and contribution to economic development. Cultivation of the F. exasperata plant will thus become an attractive venture for small- and medium-scale enterprises.

\section{Materials and methods}

\section{Plant material}

Fresh samples of the leaves of F. exasperata (Vahl) Moraceae were collected from its natural habitat in Sagamu Local Government Area of Ogun State in Nigeria. The plant was authenticated at the Forestry Research Institute of Nigeria, Ibadan, where a voucher specimen was deposited and allocated a Forestry Herbarium Institute Number 109485.

\section{Plant preparation and extraction}

The leaves of the plant were air-dried and further dried in an oven at a temperature of $50{ }^{\circ} \mathrm{C}$ for $15 \mathrm{~min}$ and grinded in a laboratory blender into fine powder after which a total of $4.8 \mathrm{~kg}$ of the ground powder was extracted by maceration using $20.5 \mathrm{~L}$ of ethanol ( $96 \%$ volume per volume $[\mathrm{v} / \mathrm{v}])$. The extract was concentrated in vacuo at $40{ }^{\circ} \mathrm{C}$ using a rotary evaporator (Buchi model R210, Switzerland) and dried in a vacuum oven. The dried extract was reduced to powder using a laboratory mill and then sieved with a $250-\mu \mathrm{m}$ mesh sieve.

\section{Extract characterisation}

Ficus exasperata leaf extract was characterised using phytochemical screening, antimicrobial assay and determination of wavelength of maximum absorption.

The phytochemical assessment of the extracts was determined by established methods to determine the presence or absence of alkaloids, flavonoids, saponins and tannins (Gul et al. 2017; Trease \& Evans 2002).

Ficus exasperata extract ( $2 \mathrm{~g}$ ) was treated with $20 \mathrm{~mL}$ of $5 \%$ tetraoxosulphate (VI) acid $\left(\mathrm{H}_{2} \mathrm{SO}_{4}\right)$ in $50 \%$ ethanol by boiling for $2 \mathrm{~min}$ and filtering through Whatman filter paper number $42(125 \mathrm{~mm})$. Ammonia $(28 \%)$ was added $(5 \mathrm{~mL})$ to the filtrate in a separating funnel to render it alkaline. A final acid extract was obtained by adding equal volumes $(5 \mathrm{~mL})$ of chloroform and $1.0 \mathrm{M}$ dilute $\mathrm{H}_{2} \mathrm{SO}_{4}$. Dragendorff's reagent (bismuth potassium iodide solution) was mixed with $2 \mathrm{~mL}$ portions of the acid extract and precipitated orange colour inferred the presence of alkaloid.

Bromine water $(10 \mathrm{~mL})$ was added to $0.5 \mathrm{~g}$ of $F$. exasperata extract. Decoloration of bromine water showed the presence of tannins.

Distilled water $(5.0 \mathrm{~mL})$ was added to the plant extract in a test tube and mixed vigorously. A few drops of olive oil were added to the frothing obtained and vigorously mixed. Appearance of foam showed the presence of saponins.

The Shinoda test was first used involving pieces of magnesium ribbon and concentrated $\mathrm{HCl}$ mixed with the plant extract after a few minutes. The appearance of a pink colour showed the presence of flavonoid. Alkaline Reagent Test was also used, in which $2 \mathrm{~mL}$ of $2.0 \% \mathrm{NaOH}$ mixture was mixed with the plant extract. The production of a concentrated yellow colour, which became colourless on adding two drops of diluted acid to the mixture, indicates the presence of flavonoids.

The antibacterial and antifungal activities of the extract were determined using the agar well diffusion method of Balouiri, Sadiki and Ibnsouda (2016). The bacteria isolates comprising four G-negative (Escherichia coli, Pseudomonas aeruginosa, Salmonella typhi and Klebsiella pneumoniae) and two G-positive (Staphylococcus aureus and Bacillus subtilis) bacteria were obtained from the Department of Medical Microbiology, University College Hospital, Ibadan, Nigeria. In addition, Aspergillus niger, Candida albicans, Rhizopus stolonifer and Penicillium notatum were obtained from the laboratory stock of the Department of Pharmaceutical Microbiology, University of Ibadan. Six different concentrations of the extracts $(6.25 \mathrm{mg} / \mathrm{mL}-200 \mathrm{mg} / \mathrm{mL})$ were prepared by diluting with dimethyl sulphoxide (DMSO). About $0.2 \mathrm{~mL}$ of $10^{-2}$ diluted, 24-h-old culture of the test organisms in nutrient broth (Oxoid Ltd, United Kingdom [UK]) was spread unto sterile prepared nutrient agar (Difco Laboratories, United States [US]) plates for bacteria and Sabouraud dextrose agar 
(Biolife Laboratories, Italy) for the fungi at $45^{\circ} \mathrm{C}$. These were then allowed to set. With the aid of a sterile cork borer, wells (6 $\mathrm{mm}$ in diameter) were bored on the plates. Whilst the bacteria isolates were seeded into the agar, the fungi were streaked unto the set agar. About $0.5 \mathrm{~mL}$ of each concentration of the extracts was dispensed into the wells and then allowed to stand for about $1 \mathrm{~h}$ for prediffusion. The bacterial plates were then incubated at $37^{\circ} \mathrm{C}$ for $24 \mathrm{~h}$ whilst the fungal plates were incubated at $25^{\circ} \mathrm{C}$ for a minimum of $48 \mathrm{~h}$. Ciprofloxacin was used as the standard for bacteria and Ketoconazole for fungi. The diameter of the zones of inhibition in the triplicate plates was measured, and the differences between cork borer $(6 \mathrm{~mm})$ and the diameters of inhibition were recorded (Bhargav et al. 2016). Positive controls (ciprofloxacin [30 $\mu \mathrm{g} /$ $\mathrm{mL}$ ] for bacteria and ketoconazole [100 $\mu \mathrm{g} / \mathrm{mL}$ ] for fungi) were used, and DMSO was also used as a negative control.

The wavelength of maximum absorption for the extract was determined using an established method (Majekodunmi, Adegoke \& Odeku 2008). One gram of the extract was placed in a $200-\mathrm{mL}$ volumetric flask, and $100 \mathrm{~mL}$ of $0.1 \mathrm{M} \mathrm{HCl}$ was added. The flask was agitated in a shaker for about $1 \mathrm{~h}$, and then filtered through a Whatman filter paper number 1 (Whatman Plc., UK). The absorption spectrum of the solution of the extract was recorded using a UV spectrophotometer (Model Cintra 6, Type GBC UV-Visible, GBC, Scientific Equipment Ltd, Victoria, Australia), and the wavelength for maximum absorption was determined. Various concentrations of the extract were prepared to contain between $0.039 \mathrm{mg} / \mathrm{mL}$ and $0.5 \mathrm{mg} / \mathrm{mL}$ of extract in $0.1 \mathrm{M}$ $\mathrm{HCl}$. The absorbance of each concentration was taken at $290 \mathrm{~nm}$ and plotted against the various concentrations to obtain the calibration curve and equation for the extract.

\section{Preparation of powder mixtures and determination of the flow properties}

Ficus exasperata extract and excipient $\left(\right.$ Avicel $^{\circledR}$, Lactose or Emcompress $^{\circledR}$ ) in drug-excipient ratio of 1:4 and 1:9 were thoroughly mixed in a tumbling mixer (026350, Froster Equipment Whetstone, England). Each batch, consisting of $50 \mathrm{~g}$ of the mixture, was stored in airtight jars.

The flow properties of the powder mixtures were determined using the methods of Okunlola and Odeku (2011). Tests conducted include density measurements (bulk density, tapped density and particle density), Carr's index, angle of repose and Hausner's ratio.

\section{Preparation of tablets}

Tablets $(500 \mathrm{mg}$ ) were prepared from the powder mixtures by compressing them for $30 \mathrm{~s}$ with predetermined loads on a Carver hydraulic hand press (Model C, Carver Inc., US). The $10.5-\mathrm{mm}$ die and flat faced punches were lubricated with a $1 \% \mathrm{w} / \mathrm{v}$ dispersion of magnesium stearate in acetone. After ejection, the tablets were stored over silica gel for $24 \mathrm{~h}$ to allow for elastic recovery so as to prevent false evaluation outcome. The weight $(\mathrm{w})$ of 10 tablets and their dimensions were measured within $\pm 1 \mathrm{mg}$ and $0.01 \mathrm{~mm}$, respectively.

\section{Mechanical properties of the tablets}

Mechanical properties (crushing strength [CS], friability [FR] and crushing strength-friability ratio [CSFR]) were measured using appropriate methods. An electronic digital CS tester was used at $29.0^{\circ} \mathrm{C} \pm 2.0^{\circ} \mathrm{C}$ to determine the load required to break the tablet diametrically. The average CS of six tablets per batch was determined, and the standard deviations were calculated. The FR of the tablets was determined with five tablets per batch using a Friabilator (Veego Scientific Devices, India) operated at 25 revolutions per minute (rpm) for $4 \mathrm{~min}$. Determinations were performed in triplicate, and the CSFR values were calculated.

\section{Release properties of the tablets}

The release properties were evaluated using disintegration times (DT), disintegration efficiency ratio (DER), dissolution profiles and dissolution times $\left(t_{50}\right.$ and $\left.t_{80}\right)$.The DT of the tablets was determined in distilled water at $37.0^{\circ} \mathrm{C} \pm 0.5^{\circ} \mathrm{C}$ using an Erweka disintegration testing apparatus (Model: Copley ZT2, Erweka Apparatebau GMBH, Germany).The end point of the test was indicated when any residue was a soft mass having no palpable core. The DER was calculated from the values of CSFR and DT as shown in Equation 1 (Alebiowu \& Itiola 2003):

$$
\mathrm{DER}=\frac{\mathrm{CSFR}}{\mathrm{DT}}
$$

The dissolution test of the tablets was determined at $37.0{ }^{\circ} \mathrm{C} \pm 0.5{ }^{\circ} \mathrm{C}$ in $900 \mathrm{~mL}$ of $0.1 \mathrm{M} \mathrm{HCl}$ using a dissolution test apparatus (DA-6D, Veego Scientific Devices, India) with the basket rotated at $50 \mathrm{rpm}$. Five-millilitre samples were withdrawn and replaced with fresh medium at fixed time intervals. The samples were diluted and filtered, and the amount of drug released was determined spectrophotometrically at $290 \mathrm{~nm}$. Each of the results is the mean of three determinations. Appropriate dissolution profiles were plotted, and the dissolution times $\left(t_{50}\right.$ and $\left.t_{80}\right)$ were obtained from the plots.

\section{Statistical analysis}

Statistical analysis was performed using Graphpad Prism 5.0 Software (GraphPad Software Inc., US) to compare diverse effects. The interaction between the type of microorganism and the concentration of the extract, the individual effects of the extract concentration and the type of microorganisms were evaluated on the antimicrobial activity of the extract. In addition, the interaction between diluent type and drugdiluent ratio was assessed on the tablet strength and dissolution. The individual effects of diluent type and drug-diluent ratio on the strength and dissolution of the tablets were also assessed. All tests were carried out using two-way analysis of variance. At $95 \%$ confidence interval, $p$ values lower or equal to 0.05 were considered the limit of significance. 


\section{Ethical consideration}

Ethical clearance was not required for the study.

\section{Results and discussion}

\section{Extract characterisation}

The plant extract contained secondary metabolites (alkaloids, flavonoids, saponins, tannins, phenols and oxalates). Alkaloids were found to be more abundant than other metabolites in the extract. This is consistent with the observation of past studies (Adebayo, Ishola \& Taiwo 2009; Sonibare et al. 2006). The presence of various active ingredients, otherwise phytoconstituents as revealed by the phytochemical screening, supports the resourcefulness of the plant extract (Ibegbulem, Ayalogu \& Uzohu 2003). Some of the phytochemical compounds detected, for example, saponin, tannin, flavonoids, terpenoid and alkaloids, have been reported to have antimicrobial activity (Cushnie \& Lamb 2005).

As shown in Table 1, the extract showed activity on the bacterial and fungal isolates at $25 \mathrm{mg} / \mathrm{mL}-200 \mathrm{mg} / \mathrm{mL}$ in a concentration-dependent manner, implying that as extract concentration increases, more molecules of the secondary metabolites were available for inhibiting the growth of the tested organisms. Generally, there were no significant differences in the antibacterial and antifungal activity of the extract against the microorganisms. At the highest concentration used $(200 \mathrm{mg} / \mathrm{mL})$, antibacterial activity ranked Salmonella typhi > Escherichia coli > Staphylococcus aureus/Pseudomonas aeruginosa/Klebsiella pneumonia $>$ Bacillus subtilis. The extract also showed higher zones of inhibition against Candida albicans and Rhizopus stolonifer with significant differences $(p<0.05)$ when compared with Aspergillus niger and Penicilium notatum. In addition, the positive controls showed higher activity for both bacteria and fungi. The activity of the extract against these organisms implies that the microorganisms may not possess a mechanism that is capable of inactivating the phytoactive ingredients in the extract. Furthermore, the organisms do not also seem to have other mechanisms, which include exclusion of the substance from the cell and modification of the target site of the substance. The presence of the phytoconstituents corroborates the antimicrobial effect obtained when the extract was tested on the microorganisms.

The extract exhibited a wavelength of maximum absorption at $290 \mathrm{~nm}$ and the calibration equation for best fitting line obtained was $Y=0.2792 \mathrm{X}+0.0096$. The regression coefficient $\left(r^{2}\right)$ obtained for the best fitting line was 0.9953 .

\section{Flow properties of powder mixtures}

The flow properties of the powder mixtures are shown in Table 2. Generally, as the concentration of the diluent increased, the values of densities, angle of repose, Carr's index and Hausner's ratio increased, showing that high concentration of diluents reduced the flow properties of the extract. For 1:4 DDR, the ranking of flow properties was Avice $^{\circledR}<$ Lactose $^{\circ}$ Emcompress $^{\circledR}$. It implies that the extract of $F$. exasperata does not require too high a concentration of diluents for it to flow adequately. Flow properties are important in tablet compression to enhance packing and compression processes.

\section{Mechanical properties of tablets}

The results of the mechanical properties are presented in Tables 3 and 4 for DDR of 1:4 and 1:9, respectively. The

TABLE 1: Antimicrobial effect of the ethanol leaf extract of Ficus exasperato.

\begin{tabular}{|c|c|c|c|c|c|c|}
\hline \multirow[t]{2}{*}{ Organism } & \multicolumn{6}{|c|}{ Zone of inhibition (mm) } \\
\hline & $25 \mathrm{mg} / \mathrm{mL}$ & $50 \mathrm{mg} / \mathrm{mL}$ & $100 \mathrm{mg} / \mathrm{mL}$ & $200 \mathrm{mg} / \mathrm{mL}$ & $\begin{array}{c}\text { Ciprofloxacin } \\
\text { (30 } \mu \mathrm{g} / \mathrm{mL})\end{array}$ & $\begin{array}{c}\text { Ketoconazole } \\
(100 \mu \mathrm{g} / \mathrm{mL})\end{array}$ \\
\hline Staphylococcus aureus & 0 & $10.0 \pm 1.1$ & $12.1 \pm 2.1$ & $14 \pm 1.3$ & $38.2 \pm 2.8$ & NA \\
\hline Escherichia coli & $10.2 \pm 0.9$ & $12.3 \pm 1.4$ & $14.2 \pm 1.7$ & $17 \pm 2.5$ & $36.2 \pm 3.4$ & NA \\
\hline Bacillus subtilis & 0.0 & $10.0 \pm 2.1$ & $12.3 \pm 2.3$ & $13 \pm 2.5$ & $36.4 \pm 4.2$ & NA \\
\hline Pseudomonas aeruginosa & 0.0 & $10.4 \pm 0.7$ & $12.5 \pm 1.9$ & $14 \pm 0.4$ & $32.5 \pm 3.7$ & NA \\
\hline Salmonella typhi & $10.1 \pm 0.2$ & $12.5 \pm 2.3$ & $14.2 \pm 1.7$ & $17 \pm 1.4$ & $36.3 \pm 2.9$ & NA \\
\hline Klebsiella pneumoniae & $10.2 \pm 0.1$ & $11.1 \pm 2.4$ & $12.0 \pm 1.2$ & $14 \pm 0.3$ & $34.3 \pm 2.3$ & NA \\
\hline Aspergillus niger & $10.0 \pm 0.3$ & $10.0 \pm 2.9$ & $12.0 \pm 2.4$ & $14 \pm 1.4$ & NA & $36.1 \pm 3.5$ \\
\hline Candida albicans & $10.5 \pm 0.4$ & $12.0 \pm 2.1$ & $14.2 \pm 1.7$ & $18 \pm 1.9$ & NA & $26.2 \pm 2.1$ \\
\hline Rhizopus stolonifera & $10.1 \pm 0.6$ & $12.3 \pm 2.2$ & $16.6 \pm 1.5$ & $18 \pm 0.7$ & NA & $24.4 \pm 1.8$ \\
\hline Penicillium notatum & $10.4 \pm 0.8$ & $10.0 \pm 3.1$ & $12.0 \pm 3.2$ & $14 \pm 0.6$ & NA & $26.3 \pm 1.3$ \\
\hline
\end{tabular}

Diluting with dimethyl sulphoxide, (negative control) $-0.0 \mathrm{~mm}$.

NA, not applicable.

TABLE 2: Flow properties of the powder mixtures of Ficus exasperata extract and diluents.

\begin{tabular}{|c|c|c|c|c|c|c|c|}
\hline Excipient & $\begin{array}{l}\text { Drug-excipient } \\
\text { ratio }\end{array}$ & $\begin{array}{c}\text { Bulk density } \\
\left(\mathrm{g} / \mathrm{cm}^{3}\right)\end{array}$ & $\begin{array}{l}\text { Tapped density } \\
\left(\mathrm{g} / \mathrm{cm}^{3}\right)\end{array}$ & $\begin{array}{l}\text { Particle density } \\
\qquad\left(\mathrm{g} / \mathrm{cm}^{3}\right)\end{array}$ & $\begin{array}{c}\text { Carr's } \\
\text { index }(\%)\end{array}$ & $\begin{array}{l}\text { Angle of } \\
\text { repose }\left({ }^{\circ}\right)\end{array}$ & $\begin{array}{c}\text { Hausner's } \\
\text { ratio }\end{array}$ \\
\hline \multirow[t]{2}{*}{ Avicel $^{\circledR}$} & $1: 4$ & 0.33 & 0.45 & 1.53 & 26.66 & 31.34 & 1.36 \\
\hline & $1: 9$ & 0.34 & 0.48 & 1.49 & 31.25 & 33.13 & 1.41 \\
\hline Emcompress $^{\oplus}$ & $1: 9$ & 0.59 & 1.00 & 2.26 & 39.00 & 41.13 & 1.64 \\
\hline \multirow[t]{2}{*}{ Lactose } & $1: 4$ & 0.52 & 0.83 & 1.70 & 31.33 & 35.00 & 1.46 \\
\hline & $1: 9$ & 0.56 & 0.91 & 1.61 & 35.16 & 36.50 & 1.54 \\
\hline
\end{tabular}


TABLE 3: Properties of Ficus exasperata herbal tablets prepared using various diluents at the drug-diluent ratio of 1:4 (mean \pm SD; $n \dagger$ ).

\begin{tabular}{|c|c|c|c|c|c|}
\hline Diluent & Applied pressure $\left(\mathrm{MN}^{-2}\right)$ & Crushing strength (N) & Friability $(\%)$ & Disintegration time (min) & Disintegration efficiency ratio \\
\hline \multirow[t]{5}{*}{ Avicel $^{\circledR}$} & 28.28 & $124.93 \pm 2.68$ & $0.82 \pm 0.01$ & $2.95 \pm 0.02$ & 51.65 \\
\hline & 56.56 & $203.80 \pm 4.14$ & $0.76 \pm 0.02$ & $3.27 \pm 0.05$ & 81.09 \\
\hline & 84.85 & $211.17 \pm 1.58$ & $0.71 \pm 0.03$ & $3.54 \pm 0.03$ & 84.97 \\
\hline & 113.13 & $291.23 \pm 3.48$ & $0.69 \pm 0.01$ & $4.03 \pm 0.10$ & 104.73 \\
\hline & 169.70 & $302.15 \pm 2.11$ & $0.67 \pm 0.02$ & $4.22 \pm 0.11$ & 106.86 \\
\hline \multirow[t]{5}{*}{ Lactose } & 28.28 & $54.70 \pm 2.11$ & $1.94 \pm 0.05$ & $3.48 \pm 0.08$ & 8.10 \\
\hline & 56.56 & $58.31 \pm 2.09$ & $1.81 \pm 0.01$ & $3.66 \pm 0.05$ & 8.80 \\
\hline & 84.85 & $64.33 \pm 1.56$ & $1.51 \pm 0.01$ & $3.75 \pm 0.01$ & 11.36 \\
\hline & 113.13 & $75.72 \pm 0.08$ & $1.05 \pm 0.02$ & $4.78 \pm 0.02$ & 15.08 \\
\hline & 169.70 & $92.80 \pm 2.14$ & $1.01 \pm 0.03$ & $5.81 \pm 0.01$ & 15.81 \\
\hline \multirow[t]{4}{*}{ Emcompress ${ }^{\circledast}$} & 28.28 & $40.43 \pm 1.21$ & $1.72 \pm 0.02$ & $3.43 \pm 0.03$ & 6.85 \\
\hline & 56.56 & $52.30 \pm 3.21$ & $1.57 \pm 0.01$ & $3.87 \pm 0.03$ & 8.61 \\
\hline & 84.85 & $58.50 \pm 2.21$ & $1.24 \pm 0.03$ & $4.21 \pm 0.02$ & 11.21 \\
\hline & 113.13 & $64.17 \pm 3.42$ & $0.91 \pm 0.02$ & $4.65 \pm 0.03$ & 15.16 \\
\hline \multirow[t]{5}{*}{ No diluent } & 28.28 & $29.88 \pm 1.23$ & $2.31 \pm 0.98$ & $3.03 \pm 1.22$ & 4.29 \\
\hline & 56.56 & $33.45 \pm 1.78$ & $2.09 \pm 0.67$ & $3.21 \pm 0.98$ & 4.97 \\
\hline & 84.85 & $39.01 \pm 2.09$ & $2.01 \pm 0.54$ & $3.87 \pm 1.21$ & 5.04 \\
\hline & 113.13 & $41.77 \pm 1.11$ & $1.98 \pm 0.79$ & $4.02 \pm 1.34$ & 5.20 \\
\hline & 169.70 & $45.79 \pm 2.13$ & $1.94 \pm 1.05$ & $4.55 \pm 1.23$ & 5.30 \\
\hline
\end{tabular}

$\dagger, n$ is varied (crushing strength -6 , friability -5 , disintegration times -6 ).

TABLE 4: Properties of Ficus exasperata herbal tablets prepared using various diluents at the drug-diluent ratio of 1:9 (mean \pm SD $\dagger$ ).

\begin{tabular}{|c|c|c|c|c|c|}
\hline Diluent & Applied pressure $\left(\mathrm{MN}^{-2}\right)$ & Crushing strength $(\mathrm{N})$ & Friability (\%) & Disintegration time (min) & Disintegration efficiency ratio \\
\hline \multirow[t]{5}{*}{ Avicel $^{\circledast}$} & 28.28 & $198.33 \pm 3.46$ & $0.79 \pm 0.02$ & $3.22 \pm 0.04$ & 77.97 \\
\hline & 56.56 & $217.00 \pm 1.07$ & $0.73 \pm 0.03$ & $3.88 \pm 0.03$ & 76.61 \\
\hline & 84.85 & $262.50 \pm 1.45$ & $0.71 \pm 0.03$ & $4.37 \pm 0.06$ & 84.60 \\
\hline & 113.13 & $324.45 \pm 1.71$ & $0.60 \pm 0.01$ & $4.88 \pm 0.12$ & 110.81 \\
\hline & 169.70 & $362.50 \pm 1.90$ & $0.52 \pm 0.04$ & $5.39 \pm 0.11$ & 129.33 \\
\hline \multirow[t]{5}{*}{ Lactose } & 28.28 & $59.94 \pm 3.28$ & $0.89 \pm 0.03$ & $4.27 \pm 0.01$ & 15.76 \\
\hline & 56.56 & $68.14 \pm 2.54$ & $0.82 \pm 0.03$ & $4.57 \pm 0.03$ & 18.17 \\
\hline & 84.85 & $77.14 \pm 3.13$ & $0.80 \pm 0.03$ & $5.74 \pm 0.03$ & 16.80 \\
\hline & 113.13 & $86.20 \pm 2.54$ & $0.68 \pm 0.03$ & $6.15 \pm 0.04$ & 20.61 \\
\hline & 169.70 & $104.00 \pm 1.07$ & $0.60 \pm 0.02$ & $6.78 \pm 0.02$ & 25.57 \\
\hline \multirow[t]{4}{*}{ Emcompress $^{\oplus}$} & 28.28 & $54.23 \pm 2.73$ & $1.11 \pm 0.05$ & $4.23 \pm 0.04$ & 11.55 \\
\hline & 56.56 & $63.23 \pm 1.21$ & $1.06 \pm 0.02$ & $4.76 \pm 0.05$ & 12.53 \\
\hline & 84.85 & $74.80 \pm 2.15$ & $1.01 \pm 0.04$ & $6.54 \pm 0.03$ & 11.32 \\
\hline & 113.13 & $82.50 \pm 1.53$ & $0.97 \pm 0.05$ & $7.13 \pm 0.05$ & 11.93 \\
\hline
\end{tabular}

$\dagger, n$ is varied (crushing strength -6 , friability -5 , disintegration times -6 ).

results indicated that CS increased whilst FR decreased with increase in the compression force and diluent concentration. Ficus exasperata extract was compressible without adding diluent, but had significantly lower $(p<0.05)$ CS and higher FR when compared with those containing diluents. Crushing strength is a measure of the bond strength and ability of tablets to withstand the stress of packaging, transportation and handling. It is dependent on the amount of the directly compressible diluent used when tablet formulation is by direct compression and compression pressure. It is also influenced by the weight, density and porosity of materials used and the space between the upper and the lower punches at the moment of compression (Ajala et al. 2017). Generally, when the concentration of the diluent increases, it has been reported to increase particle-particle contact points, resulting in the creation of more solid bonds; this produces tablets with more resistance to fracture and abrasion
(Odeku \& Itiola 2003). The ranking of CS values for the tablets containing different diluents was Avicel ${ }^{\circledR} 1: 9>$ Avicel ${ }^{\circledR} 1: 4>$ Lactose 1:9 > Emcompress ${ }^{\circledR} 1: 9>$ Lactose 1:4 > Emcompress ${ }^{\circledR} 1: 4>$ no diluent, and the trend was reversed for FR.

All tablets produced with Lactose at 1:4 DDR failed the FR test at all pressures, whereas those containing Emcompress ${ }^{\circledR}$ failed at lower compression forces. Crushing strength is a measure of tablet strength, whereas FR specifies the weakness and both parameters usually form part of a manufacturer's specification because of their importance (Odeku \& Itiola 2003). This is because tablets are subjected to several motions that may cause abrasion during manufacture, transportation and subsequent use. The intended use of a tablet determines the pharmacopoeial requirement for CS, but tablets that lose less than $1 \%$ weight by weight $(w / w)$ of their mass during FR tests are considered suitable (USP 1995). 
The values of CSFR increased with increase in compression force and concentration of diluent in the order of Avicel $^{\circledR}$ 1:9 > Avicel $^{\circledR}$ 1:4 > Lactose 1:9 > Emcompress $^{\circledR}$ 1:9 > Lactose 1:4 > Emcompress ${ }^{\circledR}$ 1:4 > no diluent, as shown in Figure $1 \mathrm{a}$ and $\mathrm{b}$. An increase in the CSFR of $F$. exasperata tablets with increase in applied pressure may be because of a rise in the number of particle interaction points, which led to an increase in the degree of bonding (Ajala et al. 2011). Crushing strength-friability ratio values provide a balance between tablet weakness and strength, and the higher the values, the more superior the mechanical properties of the tablets. Figure $1 \mathrm{a}$ and $\mathrm{b}$ showed that tablets produced with Avicel ${ }^{\circledR}$ were higher in mechanical properties than other diluents, and those with no diluent showed significantly lower $(p>0.05)$ values. Generally, higher amount of diluent in the formulation, higher compression force and presence of diluent conferred improved mechanical properties of F. exasperata herbal tablets.

\section{Release properties of the tablets}

The release properties (DT and DER) in Tables 3 and 4 showed that all tablets passed the DT requirement of not more than $15 \mathrm{~min}$ for uncoated tablets. The British

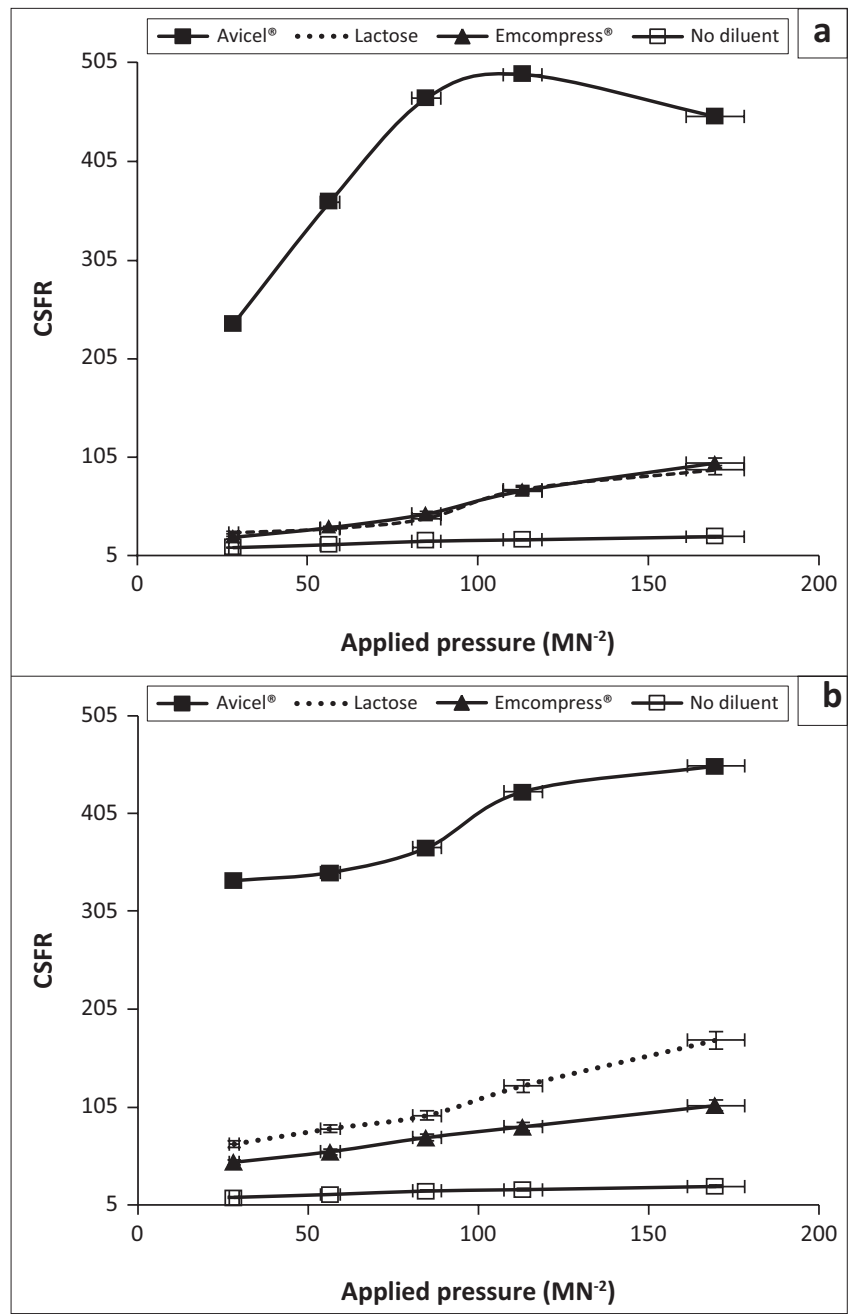

CSFR, crushing strength friability ratio; DDR, drug-diluent ratio.

FIGURE 1: The effect of applied pressure on the crushing strength-friability ratio of Ficus exasperata herbal tablets. (a) drug-diluent ratio 1:4; (b) drug-diluent ratio $1: 9$.
Pharmacopoeia stipulated a DT of not more than 15 min for uncoated tablets (British Pharmacopoeia 1998). Disintegration is directly related to dissolution and is a crucial step in the release of the active pharmaceutical ingredient in a tablet dosage form (Upadrashta \& Nuessle 1992). Disintegration times measures the time required for the tablet to crumble into particles; it is a necessary condition for dissolution and could be the rate-determining step in the process of drug absorption (Femi-Oyewo, Ajala \& Babs-Awolowo 2015).

Disintegration efficiency ratio gives a balance of the mechanical and disintegration properties as it measures CS, weakness and tablet break-up. The ranking of DER amongst the diluents was Avicel ${ }^{\circledR} 1: 9>$ Avicel $^{\circledR} 1: 4>$ Lactose 1:9 > Lactose 1:4> Emcompress $^{\circledR}$ 1:9 $>$ Emcompress $^{\circledR}$ 1:4 > no diluent.

Dissolution is an important parameter used in tablet assessment because tablets must dissolve before absorption can occur in vivo and may also be a rate-limiting step in drug bioavailability. Because drug absorption depends on amount dissolved, it is therefore vital that tablets demonstrate acceptable dissolution characteristics. Figure $2 \mathrm{a}$ and $\mathrm{b}$ showed the dissolution profiles for F. exasperata herbal tablets with highest values of DER.

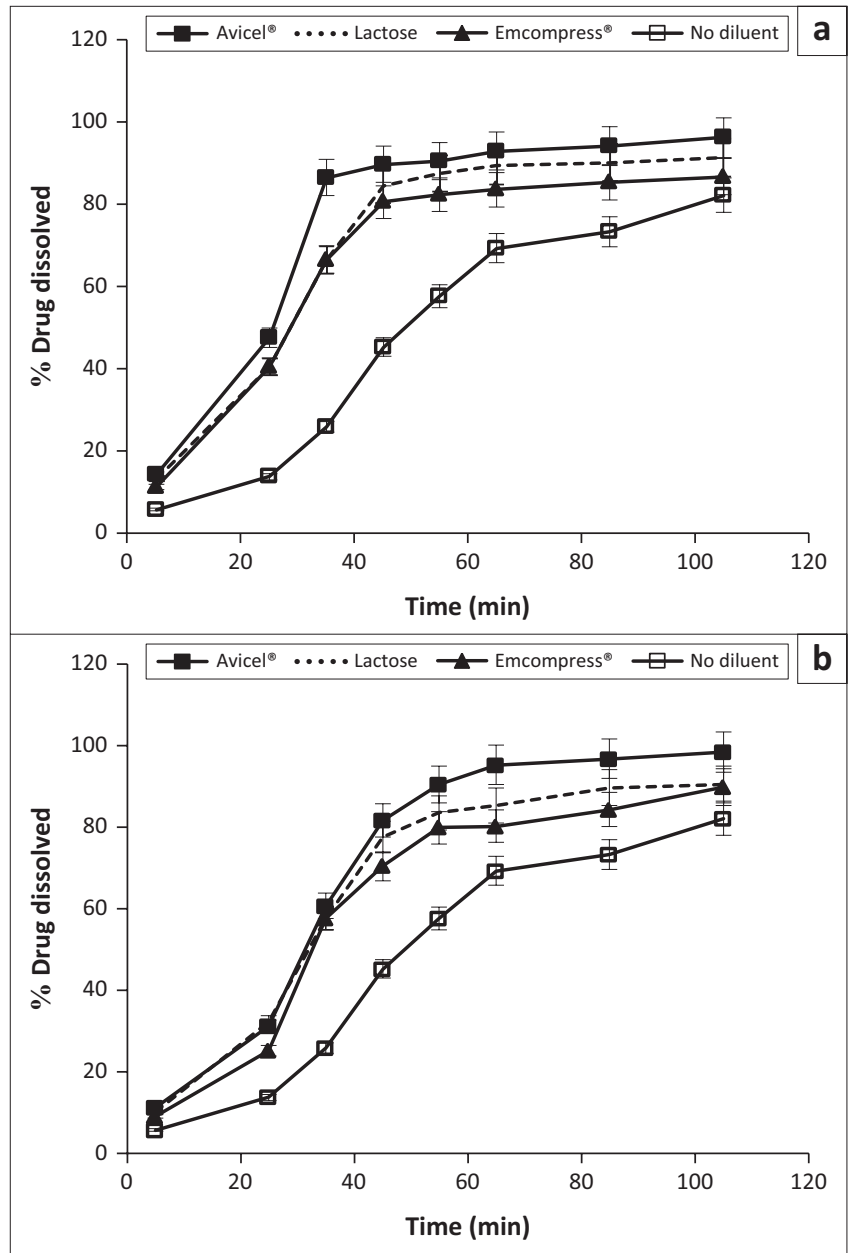

DDR, drug-diluent ratio.

FIGURE 2: The dissolution profiles of Ficus exasperata herbal tablets having highest disintegration efficiency ratio. (a) drug-diluent ratio $1: 4$; (b) drugdiluent ratio 1:9. 
TABLE 5: The dissolution times of Ficus exasperata herbal tablets having highest disintegration efficiency ratio (mean $\pm \mathrm{SD}, n=3$ ).

\begin{tabular}{lccc}
\hline Diluent & Drug-diluent ratio & $\mathrm{t}_{50}(\mathrm{~min})$ & $\mathbf{t}_{\mathbf{8 0}}(\mathrm{min})$ \\
\hline No diluent $^{*}$ & - & $50.60 \pm 3.32$ & $100.25 \pm 5.67$ \\
Avicel $^{\circledR}$ & $1: 4$ & $24.72 \pm 2.35$ & $35.64 \pm 3.34$ \\
& $1: 9$ & $32.00 \pm 3.03$ & $44.55 \pm 4.45$ \\
Lactose & $1: 4$ & $28.25 \pm 3.25$ & $42.75 \pm 3.67$ \\
& $1: 9$ & $33.10 \pm 3.33$ & $48.45 \pm 4.56$ \\
Emcompress $^{\circledR}$ & $1: 4$ & $28.50 \pm 1.25$ & $44.30 \pm 3.45$ \\
& $1: 9$ & $34.50 \pm 2.25$ & $56.50 \pm 3.24$ \\
\hline
\end{tabular}

In addition, Table 5 contained the dissolution times, that is, $t_{50}$ and $t_{80}$ (time required for $50 \%$ and $80 \%$ of Ficus exasperata extract to be released respectively from the tablet dosage) were obtained from the curves. The ranking of the dissolution times was Avice ${ }^{\circledR} 1: 4<$ Lactose 1:4 $<$ Emcompress ${ }^{\circledR} 1: 4<$ Avicel ${ }^{\circledR}$ 1:9 < Lactose 1:9 < Emcompress ${ }^{\circledR} 1: 9<$ extract alone. Tablets prepared with Lactose 1:9, Emcompress ${ }^{\circledast} 1: 9$ and extract only could not meet up with dissolution time requirement of releasing $75 \%$ w $/$ w of drug within $45 \mathrm{~min}$. Drug absorption depends on having the drug substance in the dissolved state, suitable dissolution characteristics is an important property of a satisfactory tablet.

Generally, tablets containing higher amount of diluent had higher dissolution times and this could be because of higher CS. Avicel ${ }^{\circledR}$ at both DDR fulfilled the requirement on mechanical and release properties for F. exasperata herbal tablets. Generally, the mechanical and release properties of F. exasperata herbal tablets were influenced by the diluent type, drug-diluent ratio and compression pressure.

\section{Outcome of statistical analyses}

The results of the statistical analyses presented in Table 6 showed that the activity of the extract benefitted significantly from the concentration used. The results obtained for the antimicrobial effect were extremely influenced by the type of microorganism and the concentration of the extract used. The tablet strength and dissolution also depended significantly on the type of diluent used and the drugdiluent ratio. However, interaction between diluent type and drug-diluent ratio was found not to significantly influence tablet dissolution.

\section{Conclusion}

The results obtained showed that F. exasperata extract had antibacterial and antifungal properties. The extract is moderately compressible but requires a diluent to have an adequate bond strength and appropriate release properties. In addition, the herbal tablet properties were highly influenced by diluent type, drug-diluent ratio and compression pressure; hence, these variables require cautious consideration to produce tablets with optimum parameters.

\section{Acknowledgements}

The authors hereby acknowledge Mr Festus Odewale of the Department of Pharmaceutical Microbiology, Faculty of
TABLE 6: Outcome of statistical analysis.

\begin{tabular}{|c|c|c|}
\hline Effect tested & $p$ & Remark \\
\hline $\begin{array}{l}\text { The effect of interaction between } \\
\text { organism type and extract } \\
\text { concentration on antimicrobial } \\
\text { activity }\end{array}$ & $<0.0001$ & $\begin{array}{l}\text { The interaction is extremely } \\
\text { significant }\end{array}$ \\
\hline $\begin{array}{l}\text { The effect of microorganism type } \\
\text { on antimicrobial activity of the } \\
\text { extract }\end{array}$ & $<0.0001$ & $\begin{array}{l}\text { The type of organism has extremely } \\
\text { significant influence on the } \\
\text { antimicrobial activity of the extract }\end{array}$ \\
\hline $\begin{array}{l}\text { The effect of extract concentration } \\
\text { on the antimicrobial activity of the } \\
\text { extract }\end{array}$ & $<0.0001$ & $\begin{array}{l}\text { The concentration of extract has } \\
\text { extremely significant influence on the } \\
\text { antimicrobial activity of the extract }\end{array}$ \\
\hline $\begin{array}{l}\text { The effect of interaction between } \\
\text { diluent type and drug-diluent } \\
\text { ratio on the tablet strength } \\
\text { (crushing strength) }\end{array}$ & $<0.0001$ & $\begin{array}{l}\text { The interaction is extremely } \\
\text { significant on tablet strength }\end{array}$ \\
\hline $\begin{array}{l}\text { The effect of diluent type on } \\
\text { tablet strength }\end{array}$ & $<0.0001$ & $\begin{array}{l}\text { The type of diluent used has } \\
\text { extremely significant influence } \\
\text { on tablet strength }\end{array}$ \\
\hline $\begin{array}{l}\text { The effect of drug-diluent } \\
\text { ratio on tablet strength }\end{array}$ & $<0.0001$ & Extremely significant \\
\hline $\begin{array}{l}\text { The effect of interaction between } \\
\text { diluent type and drug-diluent } \\
\text { ratio on the tablet dissolution }\end{array}$ & 0.3689 & Not significant \\
\hline $\begin{array}{l}\text { The effect of diluent type on } \\
\text { tablet dissolution }\end{array}$ & 0.0020 & Very significant \\
\hline $\begin{array}{l}\text { The effect of drug-diluent } \\
\text { ratio on tablet dissolution }\end{array}$ & 0.0003 & Extremely significant \\
\hline
\end{tabular}

Pharmacy, University of Ibadan, Ibadan, for his assistance in antimicrobial assay of the plant extract.

\section{Competing interests}

The authors hereby declare that no competing interests exist.

\section{Authors' contributions}

T.O.A. and O.A.O. designed the research concept, T.O.A. collected the plant samples, T.O.A. and A.J.O. carried out the extraction and data collection and T.O.A. conducted data analysis and interpretation. T.O.A. drafted the manuscript, O.A.O. did critical revision of the manuscript and T.O.A., A.J.O. and O.A.O. approved the final draft of the manuscript.

\section{Funding information}

The authors received no financial support for the research, authorship and publication of this article.

\section{Data availability statement}

The authors confirm that the data supporting the findings of this study are available within the article.

\section{Disclaimer}

The views and opinions expressed in this article are those of the authors and do not necessarily reflect the official policy or position of any affiliated agency of the authors.

\section{References}

Abbiw, T., 1990, 'Study of tropical shrubs and plant', Journal of Biology 23(1), 591-602. Adebayo, E.O.R., Ishola, O.S. \& Taiwo, O.N., 2009, 'Evaluation of the methanol extract of Ficus exasperate stem bark, leaf and root for phytochemical analysis and antimicrobial activity', African Journal of Plant Science 3(12), 283-287.

Agyemang, B.A. \& Togbega, A.D., 2005, 'Herbal medicine practice in Ghana', Pharmaceutical Society of Ghana News 1(1), 4-7. 
Ajala, T.O., Aremu, O.I., Segun, P.A. \& Ayorinde, J.O., 2011, 'Effect of formulation methods on the mechanical and release properties of paracetamol tablets', Journal of Pharmaceutical and Allied Sciences 8(2), 1323-1338

Ajala, T.O., Bamiro, O.A., Osahon, E.M. \& Lawal, T., 2017, 'Characterization of Cucumis sativus (Linnaeus) mucilage and its excipient potentials in metronidazole tablet formulation', Acta Pharmaceutical Sciencia 55(4), 67-84. https://doi.org/ 10.23893/1307-2080.APS.05527

Alebiowu, G. \& Itiola, O.A., 2003, 'Effects of starches on the mechanical properties of paracetamol tablets formulations. II. Sorghum and Plantain starches as disintegrants', Acta Pharmaceutica 53(4), 567-574.

Balouiri, M., Sadiki, M. \& Ibnsouda, S.K., 2016, 'Methods for in vitro evaluating antimicrobial activity: A review', Journal of Pharmaceutical Analysis 6(2), 71-79. https://doi.org/10.1016/j.jpha.2015.11.005

Bhargav, H.S., Shastri, S.D., Poornav, S.P., Darshan, K.M. \& Nayak, M.M., 2016 'Measurement of the zone of inhibition of an antibiotic', in 2016 IEEE 6th International Conference on Advanced Computing (IACC), April 2016, Bhimavaram, pp. 409-414.

Blumenthal, M., Brusse, W.R., Goldberg, A. \& Gruenwald, J., 1998, 'The complete German Commission E monographs', in M. Nathan and R. Scholten (eds.) Therapeutic guide to herbal medicines, pp. 16-25, The American Botanical Council, Austin, TX.

British Pharmacopoeia, 1998, Her Majesty's Stationary Office, London.

Buniyamin, A.A., Eric, K.I. \& Fabian, C.A., 2007, 'Pharmacognosy and hypotensive evaluation of Ficus exasperata Vahl (Moraceae)', Acta Poloniae Pharmaceutica Drug Research 64(6), 543-546.

Burkill, H.M., 1997, The useful plants of west tropical Africa, 2nd edn., vol. 4, p. 969, families M-R, Royal Botanical Gardens, Kew.

Cushnie, T.P. \& Lamb, A.J., 2005, 'Antimicrobial activities of flavonoids', Internationa Journal of Antimicrobial Agents 26(5), 343-347. https://doi.org/10.1016/j. ijantimicag.2005.09.002

Dias, D.A., Urban, S. \& Roessner, U., 2012, 'A historical overview of natural products in drug discovery', Metabolites 2(2), 303-336. https://doi.org/10.3390/metabo2020303

Ekor, M., 2014, 'The growing use of herbal medicines: Issues relating to adverse reactions and challenges in monitoring safety', Frontiers in Pharmacology 4(1) 177. https://doi.org/10.3389/fphar.2013.00177

Femi-Oyewo, M.N., Ajala, T.O. \& Babs-Awolowo, D., 2015, 'The compaction, mechanical and disintegration properties of modified Pennisetum glaucum (Poaceae) starch in directly compressed chloroquine tablet formulations', Journa of Applied Pharmaceutical Science 5(2), 43-50. https://doi.org/10.7324/JAPS. 2015.50207
Gul, R., Jan, S.U., Faridullah, S., Sherani, S. \& Jahan, N., 2017, 'Preliminary phytochemical screening, quantitative analysis of alkaloids, and antioxidant activity of crude plant screening, quantitative analysis of alkaloids, and antioxidant activity of crude plant Journal 2017, 5873648(1), 1-7. https://doi.org/10.1155/2017/5873648

Ibegbulem, C.O., Ayalogu, E.O. \& Uzohu, M.N., 2003, 'Phytochemical and antinutritional contents and hepatotoxicity of zobo (Hibiscus sabdariffa) drink', Journal of Agriculture and Food Sciences 1(1), 335-339.

Joy, P.P., Thomas, J., Mathew, S. \& Skaria, B.P., 2001, Medicinal plants-tropical horticulture, 1st edn., vol. 2, pp. 449-632, Naya Prokash, Calcutta.

Majekodunmi, S.O., Adegoke, O.A. \& Odeku, O.A., 2008, 'Formulation of the extract of the stem bark of Alstonia boonei as tablet dosage form', Tropical Journal of Pharmaceutical Research 7(2), 987-994. https://doi.org/10.4314/tjpr.v7i2.14683

Meyer, J.J.M., Afolayan, A.J. \& Taylor, M.B., 1996, 'Inhibition of Herpes simplex virus by aqueous extract from shoots of Helichrysum aureonites (Astoraceae)', Journal of Ethnopharmacology 51(1), 41-43. https://doi.org/10.1016/0378-8741(96)01387-6

Odeku, O.A. \& Itiola, O.A., 2003, 'Evaluation of the effects of khaya gum on the mechanical and release properties of paracetamol tablets', Drug Development \& Industrial Pharmacy 29(3), 311-320. https://doi.org/10.1081/DDC-120018205

Odunbaku, O.A., Ilusanya, O.A. \& Akasoro, K.S., 2008, 'Antibacterial activity of ethanolic leaf extract of Ficus exasperata on Escherichia coli and Staphylococcus albus', Scientific Research \& Essay 3(11), 562-564.

Okunlola, A., Adewoyin, B.A. \& Odeku, O.A., 2007, 'Evaluation of pharmaceutical and microbial qualities of some herbal medicinal products in south western Nigeria', Tropical Journal of Pharmaceutical Research 6(1), 661-670. https://doi. org/10.4314/tjpr.v6i1.14644

Okunlola, A. \& Odeku, O.A., 2011, 'Evaluation of starches obtained from four Dioscorea species as binding agent in chloroquine phosphate tablet formulations', Saud Pharmaceutical Journal 19(2), 95-105. https://doi.org/10.1016/j.jsps.2011.01.002

Sofowora, A., 1993, Medicinal plants and traditional medicine in Africa, pp. 191-289, Spectrum Books Ltd., Ibadan.

Sonibare, M.O., Isiaka, A.O. \& Taruka, M.W., 2006, 'Constituents of Ficus exasperata leaves', Natural Product Communication 1(9), 23-26. https://doi.org/10.1177/ $1934578 \times 0600100912$

Trease, G.E. \& Evans, W.C., 2002, A textbook of pharmacognosy, pp. 214-393, 15th edn., Bailliere Saunders, Philadelphia, PA.

Upadrashta, P.R. \& Nuessle, N.O., 1992, 'Chitosan as a tablet binder', Drug Development and Industrial Pharmacy 18(15), 1701-1708. https://doi.org/10.3109/036390 49209040896

US Pharmacopeia National Formulary USP 23/NF 18, 1995, United States Pharmacopeial Convention. Inc., Rockville, MD. 